\title{
Bitlis Katı Atık Tesisi Çevresindeki Hypericum scabrum L., Achillea vermicularis Trin, Anchusa azurea Miller var. azurea Gard. Dict. Bitkilerinin Ağır Metal İçeriklerinin Belirlenmesi
}

\author{
Şükrü HAYTA*, Nurfeşan AVCİL \\ Bitlis Eren Üniversitesi Mühendislik Mimarlık Fakültesi, Çevre Mühendisliği Bölümü \\ (ORCID: 0000-0003-1008-487X) (ORCID: 0000-0002-3619-3890)
}

\begin{abstract}
Öz
Son yıllarda ağır metaller ile kirlenen toprakların temizlenmesinde (fitoremediasyon) hiperakümülatör bitkilerin kullanılması ve bu özelliğe sahip bitkilerin tespit edilmesi oldukça önemlidir. Bu çalışmada bazı bitkilerin bünyelerinde ağır metal biriktirebilme yetenekleri (hiperakümülatör) tespit edilmeye çalışılmıştır. Çalışma alanı olarak Bitlis İli Güroymak ilçesi sınırları içerisinde bulunan Katı Atık Entegre Bertaraf Tesisi çevresi seçilmiş ve bu alandan doğal olarak yetişen Hypericum scabrum L., Achillea vermicularis Trin, Anchusa azurea Miller var. azurea Gard. Dict. türlerine ait örnekler toplanmıştır. Bu bitkilerinin yetiştiği alandan alınan toprak numuneleri ile kök, gövde, yaprak ve çiçek gibi kısımlarına ayrılan bu bitkiler üzerinde çalışılarak, $\mathrm{Ca}, \mathrm{Mg}, \mathrm{Fe}, \mathrm{Mn}, \mathrm{Zn}, \mathrm{Cu}, \mathrm{Pb}$, $\mathrm{Cr}$, Ni ve Cd elementlerinin konsantrasyonları incelenmiştir. Ağır metal analizleri ICP-MS cihazı kullanılarak yapılmıştır..
\end{abstract}

Anahtar kelimeler: Hiperakümülatör, Ağır metal, Bitlis.

\section{Determination of Heavy Metal Contents of Hypericum scabrum L., Achillea vermicularis Trin, Anchusa azurea Miller var. azurea Gard. Dict. Plants Around Bitlis Solid Waste Landfill}

\begin{abstract}
At present, it is very important to use hyperaccumulator plants to clean soils contaminated with heavy metals (phytoremediation method) and to identify plants with this characteristic. In this work, it is studied to detect the ability of accumulating heavy metal (hyperacumulator) of some plants in their bodies. The area around the Solid Waste Integrated Disposal Facility located within the boundaries of Güroymak district of Bitlis Province selected and Hypericum scabrum L., Achillea vermicularis Trin, Anchusa azurea Miller. azurea Gard. Dict. naturally grown samples were collected from this area. Soil samples taken from the area where these plants grow with on the basis of the contents of calcium $(\mathrm{Ca})$, magnesium $(\mathrm{Mg})$, copper $(\mathrm{Cu})$, lead $(\mathrm{Pb})$, zinc $(\mathrm{Zn})$, chromium $(\mathrm{Cr})$, nickel $(\mathrm{Ni})$, iron $(\mathrm{Fe})$, manganese $(\mathrm{Mn})$ and cadmium $(\mathrm{Cd})$ were investigated. Heavy metal analyzes were performed using ICP-MS.
\end{abstract}

Keywords: Hyperaccumulator Heavy metals, Bitlis.

\section{Giriş}

Sanayileşme ve nüfusun giderek artması tüm ekosistemi etkilemekte ve bunun sonucu olarak da çevresel problemler ortaya çıkmaktadır. Hava ve su gibi çevre bileşenlerinin yanında toprak da önemli bir bileşendir. Çünkü insan yaşamanın devam etmesi için gerekli olan temel bileşenlerin başında toprak yer almaktadır. Toprağın en önemli özelliklerinden birisi besin maddelerinin çoğunu içermesidir. Sanayileşmenin gün geçtikçe artması toprakta ağır metal birikimine sebep olmaktadır. Özellikle $\mathrm{Hg}, \mathrm{Cd}$ ve $\mathrm{Pb}$ gibi ağır ya da toksik metaller sayesinde ortaya çıkan çevre kirliliği, besin zincirini ve tüm dünyayı

*Sorumlu yazar: sukruhayta@hotmail.com

Geliş Tarihi: 11.06.2019, Kabul Tarihi: 20.08.2019 
tehdit eder hale gelmiştir. Urano (2010) [1], birçok ağır metalin toprakta doğal olarak bulunmasıyla beraber farklı endüstriyel uygulamalar sonucu çevreye yayıldığını belirtmiş̧ir. Toprakta bulunan metal derişimi genel olarak 1 ila $100.000 \mathrm{mg} \mathrm{kg}^{-1}$ arasında değişkenlik göstermektedir. Ağır metallerin yüksek konsantrasyonlarda bulunması toprağın organik yapısının bozulmasına, ürününün verim ve kalitesinde düşüşlere neden olmakta [2] ve bu nedenle insan ve diğer canlılar için olumsuz etkilere yol açmaktadır [3].

Topraktan ağır metallerin bertaraf edilmesi için hendek açma, kimyasal stabilizasyon, toprak yıkama ve gömme gibi teknikler kullanılmaktadır. Ancak bu tekniklerin uygulanabilirliği zor ve maliyetleri yüksek olduğu için pratik değildirler. Toprakta yetişen bazı bitkiler bünyelerinde bir kısım ağır metalleri yüksek oranda biriktirme kabiliyetine sahiptir. Ağır metalleri bünyelerinde toplayan bitkiler toksik etkiye sahip kirleticileri toprak üstü ve toprak altı dokuları vasıtasıyla bünyelerine alabilmektedirler. Literatürde bu tür bitkiler hiperakümülatör bitki olarak tanımlanmaktadır. Hiperakümülatör bitkiler, normal bitkilere göre toksik metalleri toprak altı dokularında yani köklerinde tutma özelliğine sahip, derişimleri 1000 ppm ile 10.000 ppm'e kadar metal biriktirme yeteneğine sahip bitkilerdir. Bitkiler bu birikim işlemini köklerinin yanı sıra gövde ve yapraklarında da yapabilmektedirler. Bakır $(\mathrm{Cu})$, kadmiyum $(\mathrm{Cd})$, kobalt $(\mathrm{Co})$, mangan $(\mathrm{Mn})$, nikel $(\mathrm{Ni})$, çinko $(\mathrm{Zn})$, kurşun $(\mathrm{Pb})$, demir $(\mathrm{Fe})$, magnezyum $(\mathrm{Mg})$, krom $(\mathrm{Cr})$ gibi metaller bu bitkiler tarafindan en çok arıtılabilen metallerdendir. Hiperakümülatör bitkiler ayrıca organik kirleticiler ve radyoaktif elementleri de yapılarına alabilmektedirler [4].

$\mathrm{Bu}$ çalışmada, ağır metal birikimine neden olabilecek bir potansiyele sahip olan Bitlis İli Katı Atık Entegre Bertaraf Tesisi çevresinde doğal olarak yetişme alanı gösteren bazı hiperakümülatör bitkilerin ağır metalleri yaprak, gövde veya köklerinde absorbe ederek nasıl bir etki yaptığ1 incelenmiştir. Bu kapsamda Bitlis İli, Güroymak İlçesi’nde bulunan Katı Atık Entegre Tesisinin etrafında bir izleme çalışması yapılmıştır.

\section{Materyal ve Metot}

\subsection{Araştırma ve Çalışma Alanı}

Çalışma alanı olarak Bitlis ilinin doğusunda, Kirkor dağı (Gökgören dağı) üzerindeki Kurukaval Tepesinin (2478 m) kuzeydoğu yönünde, Şikirin Tepesinin güneydoğusunda (2658 m) yer alan, deniz seviyesinden yüksekliği $1700 \mathrm{~m}$ civarında olan, yaklaşı 50 ha'lı bir alan üzerine kurulmuş ve Güroymak İlçesi Bellektepe civarında konumlanmış Katı Atık Entegre Bertaraf Tesisi çevresi olarak belirlenmiştir. Şekil 1'de çalışma alanının Google earth görüntüsü, Şekil 2' de ise Bitlis Katı Atık Tesisi'nin bitki örneğinin alındığı bir bölge gösterilmiştir.

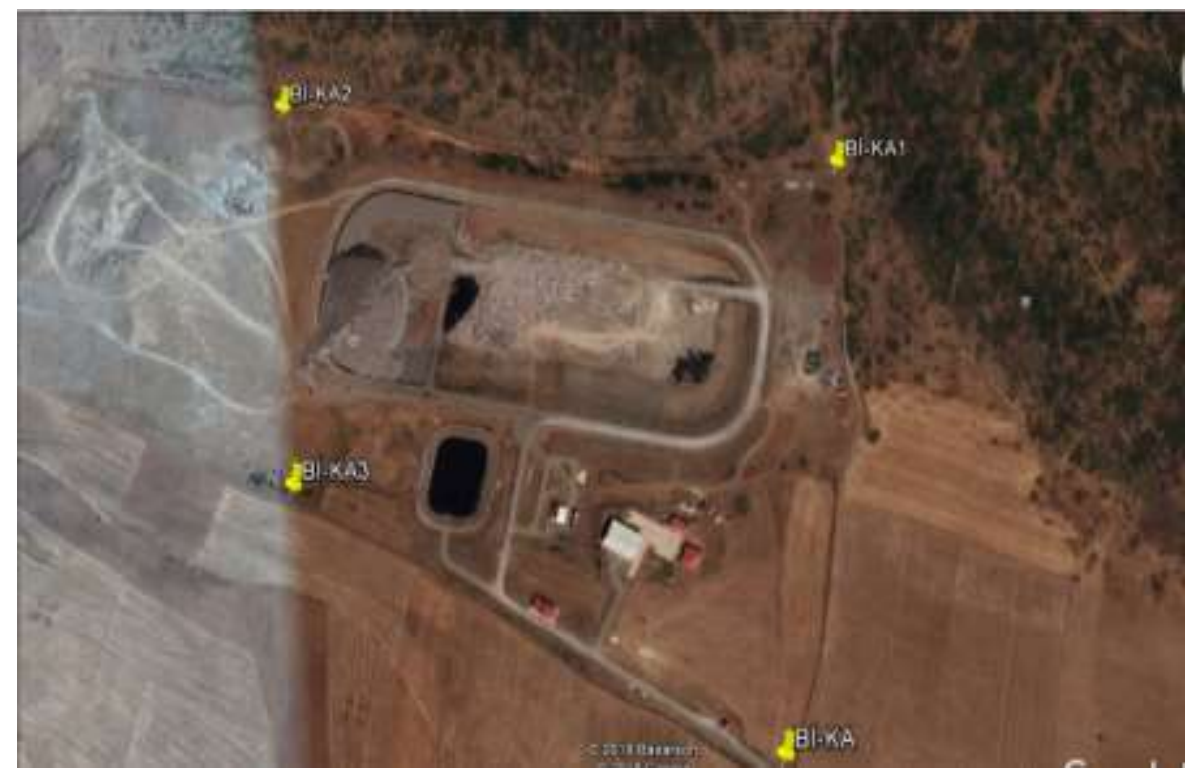

Şekil 1. Çalışma Alanının Google Earth Görüntüsü 


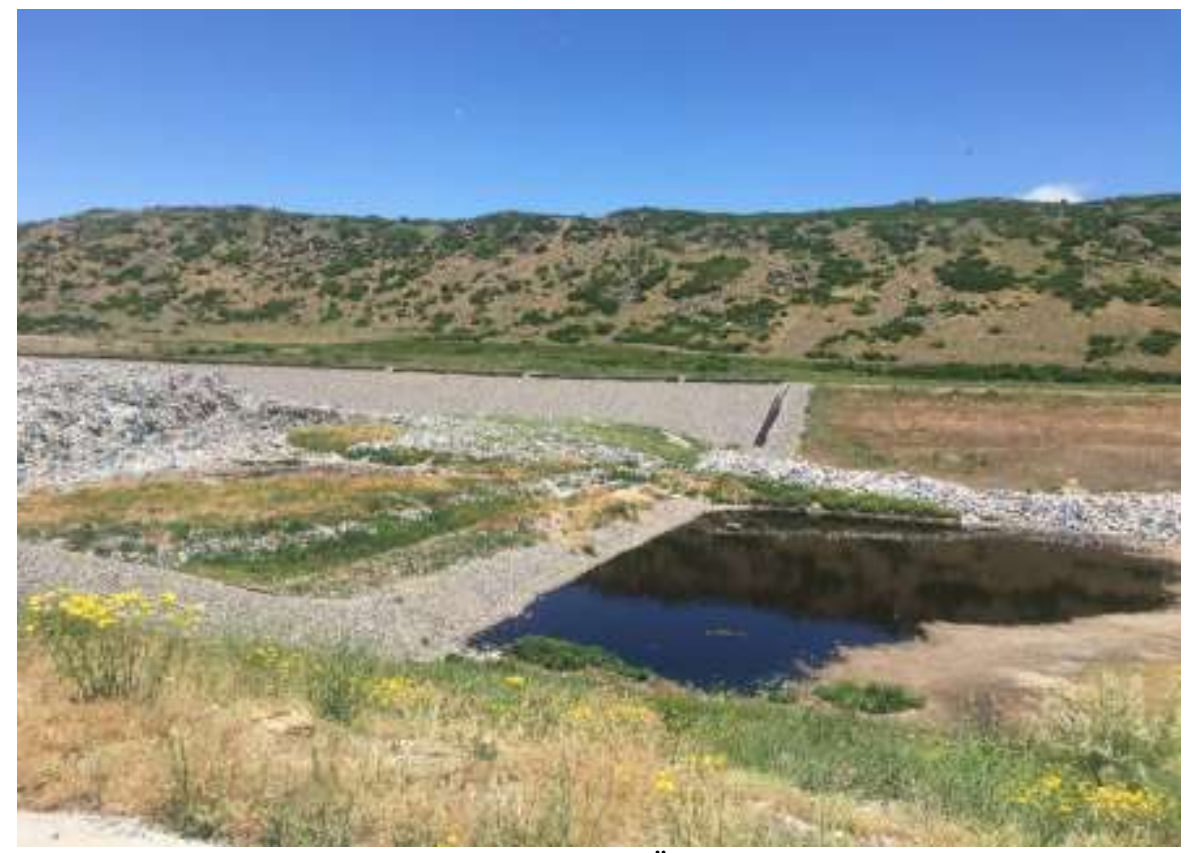

Şekil 2. Bitlis Katı Atık Tesisi Bitki Örneğinin Alındığı Bir Bölge

\subsection{Kullanılan Bitkiler}

Hypericum scabrum L.: Bitki çok yıllık, gövde 11-50 cm boyunda, dik ya da tabanda yatık, tabanda dallanmış, tüysüz, tepesi kırmızı guddeli uzantılı dallanmamış skabrit ya da nadiren pürüzsüz ve guddesiz. Gövde yaprakları 2-5 x 8-20 mm, oblong ya da lanseolattan oblong eliptike ya da şeritsi, genellikle düz, mukronattan yuvalağa, tüysüz ya da hemen hemen dalgalı-papillalı, nadiren donuk mavimsi yeşil, koltuktaki sürgün yapraklar daha küçük ve daha dar. Hypericum scabrum L. (Şekil 3) kuru kayalık yamaçlarda ve açık ormanlık alanlarda yayılış gösterir ve çiçeklenme dönemi MayısTemmuz ayları arasındadır [5]. Antispazmodik, sedatif ve anti-inflamatuar özelliklere sahip ve ülkemizde tıbbi bir bitki olarak kullanılan otsu çok yıllık bir bitkidir [6]. Türkiye'de, bu bitkinin toprak üstü kısımları kullanılarak bir cilt merhemi hazırlanmış ve sedef hastalığına karşı ilaç olarak kullanılmıştır. Ayrıca bu bitki çok güçlü antibakteriyel [7] ve antimikrobiyal [8] özelliklerinden dolayı önemli bir farmakolojik potansiyele sahiptir.

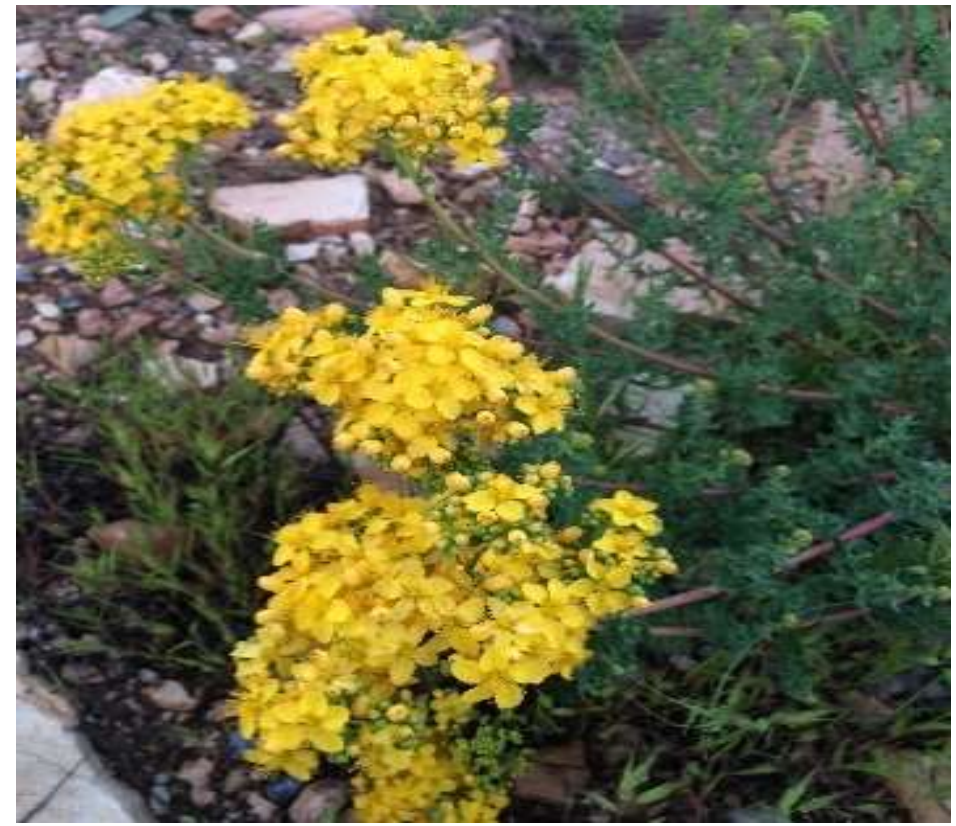

Şekil 3. Hypericum scabrum L. 
Achillea vermicularis Trin.: Bitki kalın odunsu rizomlu. Gövde $15-65 \mathrm{~cm}$, yükselici, çok sayıda, uzun steril sürgünlü, dallanmış, sık yapraklı, silindirik, boyuna çizgili, beyaz yatık tomentozdan tüysüze kadar. Yapraklar homomorfik, lineer, 0,5-2,5 x 0.1-0,3 cm, sapsız, pinnatisekt, \pm orak şeklinde içe doğru kıvrılmış ya da eğri büğrü, sık imbrikat ya da aralıklı segmentlere bölünmüş; segmentler 0,3-1 x 1-1,5 mm, 3 loplu ya da 3 partite, ortadaki lop kenardakilerden daha büyük, loplar oblongdan dairemsiye kadar, 0,3-1 x 0,5 mm, 100 kenarı kikencikli, uçtaki dikencik kenardakilerden uzun, üst gövde yaprakları daha kısa, korimbus'a erişmez, sık kısa dağınık tüylü. Çiçek durumu sapı (3-) 5-28 mm. Kapitulum (12-40(-45), korimbus 1-8(-10) cm genişliğinde. İnvolukrum yarı küremsiden genişçe yarı küremsiye kadar, 2-6 x 2,5-8 mm, tabanı yuvarlak. Çiçeklenme dönemi Haziran-Eylül ayları arasında olup, step, kayalık ve taşlık yamaçlarda yayılış gösterirler (Şekil 4) [9].

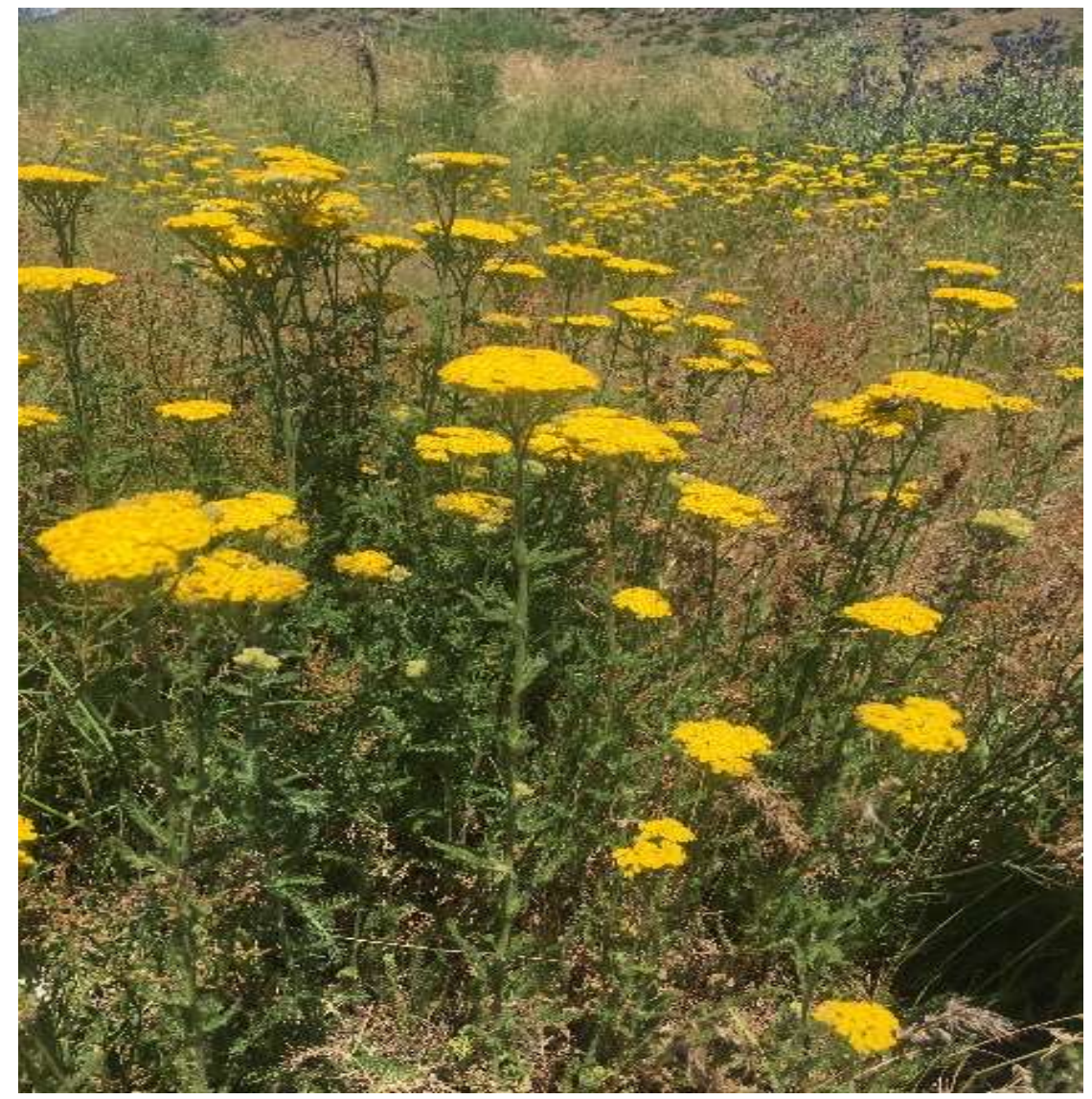

Şekil 4. Achillea vermicularis Trin.

Anchusa azurea Miller var. azurea Gard. Dict.: İki yıllık veya çok yıllık, oldukça uzun ve özellikle nemli bölgelerde oldukça kalın kazık köklere sahip. Bitki otsu gövdeli, toprak üstü gövdesi $30-115 \mathrm{~cm}$. uzunluğunda, gövde tamamen strigoz tüylerle kaplı. Bazal yapraklar, linear-lanceolate, 7-30×1,2-3.5 $\mathrm{cm}$. uzunluğunda. Meyvelenme döneminde özellikle yaprakların uç kısmındaki tüyler skabroz yapıda ve tabanı tüberküllü; yapraklarda ana damarlar ayırt edilebilmektedir. Çiçek durumu panikül, meyveli dönemde gevşek panikül. Çiçeklenme dönemi Nisan-Temmuz ayları arasında olup, yol kenarları, açık alanlar, tarlalar ve step alanlarda yayılış gösterirler (Şekil 5) [10]. 


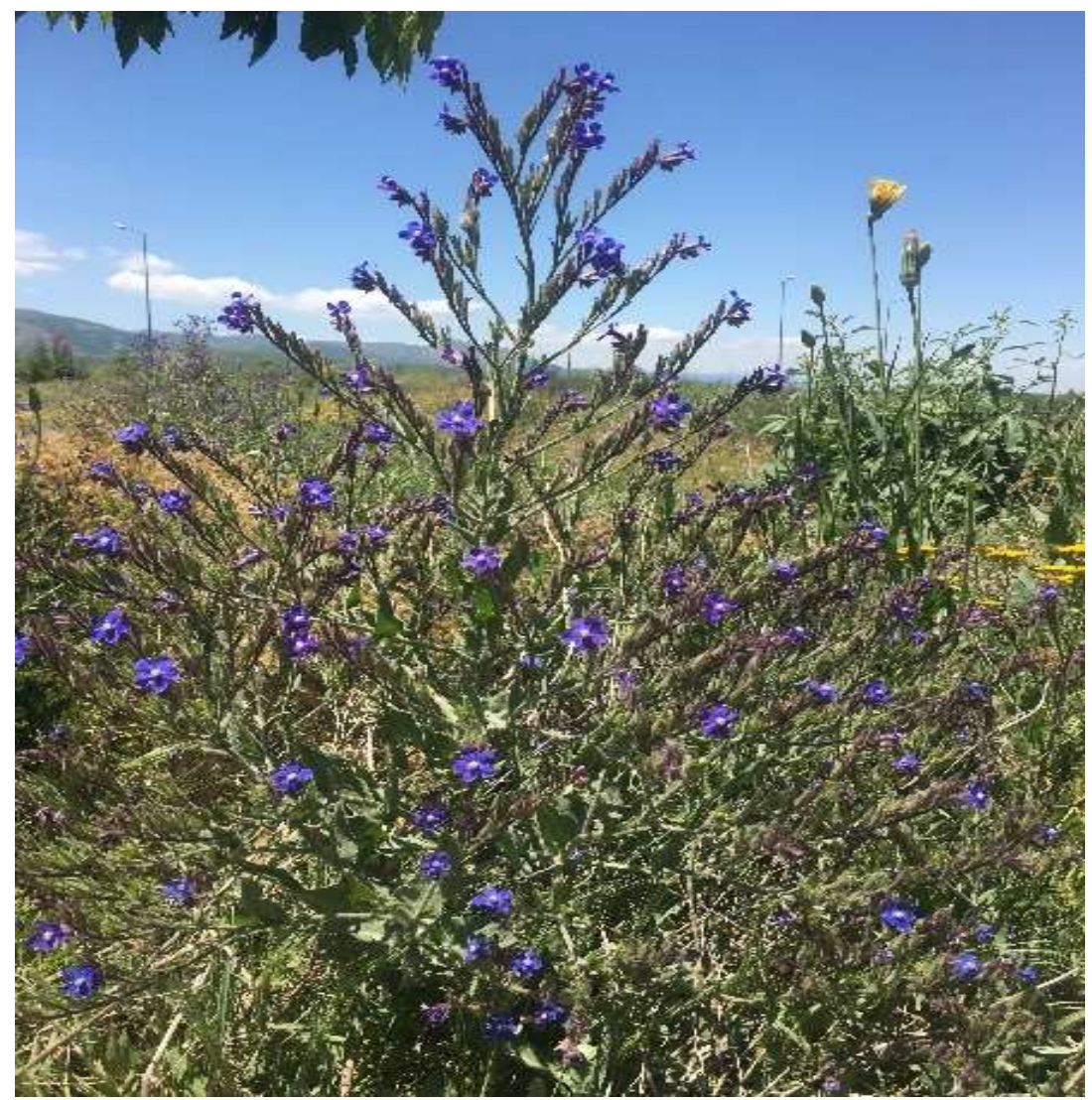

Şekil 5. Anchusa azurea Miller var. azurea Gard. Dict.

\subsection{Ağır Metal Analizi}

Çalışmamızda ağır metal birikimine neden olabilecek bir potansiyele sahip olan Bitlis İli Katı Atık Entegre Bertaraf Tesisi çevresinde doğal olarak yetişebilen ve bu bölgede baskın özelliğe sahip 3 farklı Anchusa azurea Miller var. azurea Gard. Dict., Achillea vermicularis Trin., Hypericum scabrum L., bitki türü toplanmıştır. Toplanan bu türler teşhis edilmek amacıyla Çevre Mühendisliği Laboratuvarına getirilmiştir. Flora of Turkey adlı eser ve Botanik kılavuzu yardımıyla bu türlerin teşhisi yapılmıştır. Teşhisleri yapılan bu türler daha sonra yaprak, gövde, çiçek, kök gibi kısımlara ayrılmıştır. Buradaki amacımız bitkinin sahip olduğu toprak altı ve toprak üstü organlarında birikim gösteren ağır metal içeriklerinin ayrı ayrı tespit edilmesi ve bu organlar arasında karşılaştıılma yapılabilmesidir. Yaprak, gövde, çiçek, kök gibi kısımlarına ayrılan bu bitkiler öncelikle laboratuvardaki çeşme suyuyla yıkanmıştır. Daha sonra ELGA PURELAB-Q DV25 marka saf su cihazından alınan sudan geçirilen bu parçalar kurutulmak üzere ayrı ayrı filtre kağıtları üzerine serilmiştir. Kurutulduktan sonra MST55 marka Etüv cihazında her bir bitki parçası filtre kağıtlarına sarılı bir biçimde $80{ }^{\circ} \mathrm{C}$ ' de 24 saat bekletilmiştir. 24 saat sonunda bu bitki numuneleri ayrı ayrı ağZı kapalı poşetlere konulup dolaplara kaldırılmıştır. Ayrıca bu türlerin toplandığı alanda birbirinden farklı görülen 3 farklı alandan toprak numuneleri alınmıştır. Yine bu toprak numuneleri ön işlem yapılmak üzere Çevre Mühendisliği Laboratuvarına getirilmiştir. Uygun bir yerde bu toprak numuneleri filtre kağıtlar üzerine serilerek iki hafta boyunca havalandırılmıştır. Toprak numuneleri ön işlem ve analizleri yapılmak üzere plastik ağzı kapalı poşetlere alınmış ve dolaplara konulmuştur. Numuneler ilk olarak mikrodalga cihazında yakma işlemine tabi tutularak, 0,5 gr numune alınarak üzerine $6 \mathrm{~mL} \% 65$ lik $\mathrm{HNO}_{3}$ ve $2 \mathrm{~mL} \% 30$ luk $\mathrm{H}_{2} \mathrm{O}_{2}$ eklenmiştir. Yakılan numuneler ICP-MS cihazında okuma yapılabilmesi için 50 kat \%2 lik $\mathrm{HNO}_{3}$ ile seyreltilmiştir (200 uM numune+ $9800 \mathrm{uM} \% 2$ lik $\mathrm{HNO}_{3}$ ). ICP-MS cihazında yapılan okumada mikrodalgadaki seyreltmede kullanılan peroksit ve nitrik asit te ayrıca blank olarak yakma işlemine tabi tutulup special blank olarak okutularak ve bu değer ICP okumasında sonuçlardan düşülerek hesaplama yapılmıştır. Yapılan 50 katlık seyreltmelerde ICP cihazında hesaplanarak sonuçlar excel dosyasına aktarılmıştır. 


\section{Bulgular ve Tartışma}

Çalışmamızda Bitlis İli Katı Atık Tesisi çevresinde en fazla yayılış gösteren 3 tür (Anchusa azurea Miller var. azurea Gard. Dict., Achillea vermicularis Trin., ve Hypericum scabrum L.) ile bunlar1 çevreleyen toprak örnekleri ICP*MS cihazı kullanılarak $\mathrm{Ca}, \mathrm{Cd}, \mathrm{Cr}, \mathrm{Cu}, \mathrm{Fe}, \mathrm{Mg}, \mathrm{Mn}, \mathrm{Ni}, \mathrm{Pb}$ ve $\mathrm{Zn}$ ağır metal konsantrasyonları belirlenmiştir. Ayrıca bu bitkilerin hangi ağır metalleri biriktirebilme yetenekleri olduğu tespit edilmeye çalışılmıştır.

Kadmiyum (Cd), bitkilerin büyüme, metabolizma ve su durumunu etkileyen, oldukça toksik, esansiyel olmayan bir elementtir [11]. Cd toksisitesinin nedenlerinden biri, diğer elementlerle olan etkileşimidir. Örneğin, Hernândez vd. (1998) [12] Mn alımındaki azalma ile Cd'nin varlığı arasında bir korelasyon bulmuştur. Kadmiyum ayrıca zarların lipidlerine, proteinlerine, pigmentlerine ve nükleik asitlerine zarar vererek bitkilerin ölümüne neden olan reaktif oksijen türlerini ve serbest radikalleri serbest bırakarak oksidatif stres üretir [13]. Daha önceki çalışmalar, kadmiyumla uyarılan morfofizyolojik değişiklikler keşfetmekte başarısız olmuştur [14-15]. Ancak bazı çalışmalar, yüksek Cd konsantrasyonlarında sürgünlerde ultrastrüktürel değişiklikler yapma olasılığını göstermiştir [16].

$\mathrm{Cd}$, topraklarda oldukça hareketlidir ve alım mekanizmaları iyi bilinmemekle birlikte bitkiler için kolaylıkla kullanılabilir [17]. Chaney (1989) [18] tarafından bildirilen Cd nin fitotoksik aralığı (5$700 \mathrm{mg} \mathrm{kg}^{-1}$ ) değerleri arasında değişkenlik gösterir. Buna karşılık Allen (1989) [19] kirletilmemiş ortamlarda bitkilerdeki $\mathrm{Cd}$ içeriğinin $0,01-0,3 \mathrm{mg} \mathrm{kg}^{-1}$ olduğunu savunmaktadır. FAO/WHO'nun bitkilerde kabul ettiği Cd sınır değeri $0,5 \mathrm{mg} \mathrm{kg}^{-1}$ dır. Bitki dokularındaki Cd konsantrasyonundaki farklılık esas olarak kentsel atık su, gübreler ve yol trafiğinden kaynaklandığı düşünülebilir. Araştırma sonuçlarına göre Cd birikim oranı en yüksek seviyede Hypericum scabrum L. bitkisinin gövde kısmında $\left(0,093 \mathrm{mg} \mathrm{kg}^{-1}\right)$ tespit edilmiştir. Ölçülebilen en düşük Cd konsantrasyonu Anchuza azurea var. azurea bitkisinin gövde örneklerinde $0,001883 \mathrm{mg} \mathrm{kg}^{-1}$ olarak belirlenmiştir. Bu verilere göre yaptığımız analizler sonucunda $\mathrm{Cd}$ herhangi bir bitkide fitotoksik özellik gösterebilecek bir konsantrasyonda görülmemiştir.

Krom (Cr), bitkiler için toksik olarak kabul edilen bir elementtir. Allen (1989)'e göre, 0,5 mg $\mathrm{kg}^{-1}$ den daha yüksek Cr konsantrasyonları bitkiler için toksik etki gösterir. Havadaki ağır metal konsantrasyonları büyük oranda vejetatif mevsime bağlıdır. Özellikle büyüme mevsimi sonunda birikim keskin bir şekilde artabilir [20]. Yapı malzemelerinin ve tarımsal kimyasalların çöp dökümleri, Cr biyoakümülasyonunun ana kaynağı olarak düşünülebilir. Allen (1989)'e göre, bitkilerde bulunmasına izin verilebilen Cr konsantrasyonu $0,05-0,5 \mathrm{mg} \mathrm{kg}^{-1}$, sedimentlerde ise sınır değerler $10-200 \mathrm{mg} \mathrm{kg}^{-}$ ${ }^{1}$ 'dır. FAO/WHO'nun bitkilerde kabul ettiği Cr sınır değeri $0,5 \mathrm{mg} \mathrm{kg}^{-1}$ 'dır. Bu sonuçlara bakıldığında $\mathrm{Cr}$ çalıştığımız bitkiler içerisinde fitotoksik sınırlar içerisinde kalmıştır.

Bakır (Cu), bitki besleme için hayati önem taşımaktadır ve oksidasyon-indirgemenin çeşitli enzimatik faaliyetleri için gereklidir. $\mathrm{Cu}$, köklerde birikme eğilimi gösterir ve neredeyse yerüstü organlara translokasyona girer [21]. Bu çalışmada, kökler rizomlarda $\mathrm{Cu}$ miktarı \%70 azaldığından bir tür filtre gibi davranıyordu. Bu filtre etkisi, rizomları ve sürgünleri bakır kaynaklı yaralanmalardan korumada en etkili stratejidir [22]. Bununla birlikte, uzun süreli maruz kalınması durumunda, yüksek $\mathrm{Cu}$ konsantrasyonları kök enerji metabolizmasını etkileyebilir [23]. Cu konsantrasyonun bitkilerdeki fitotoksik aralığı $\left(25-40 \mathrm{mg} \mathrm{kg}^{-1}\right)$ 'dir [18]. Alanın ve tarımın ana iş olarak yüksek kentleşmesi nedeniyle, Bitki dokularındaki $\mathrm{Cu}$ konsantrasyonlarının pestisit ve kanalizasyon çamurundan kaynaklanması muhtemeldir [24].

Allen (1989)'e göre, sediment ve bitki örneklerinde bulunması gereken Cu konsantrasyonu 2,5 - $25 \mathrm{mg} \mathrm{kg}^{-1}$ 'dır. FAO/WHO'nun bitkilerde kabul ettiği $\mathrm{Cu}$ sınır değeri $5 \mathrm{mg} \mathrm{kg}^{-1}$ ' dır. En yüksek $\mathrm{Cu}$ konsantrasyonu Hypericum scabrum bitkisinin çiçek kısmında $1,725 \mathrm{mg} \mathrm{kg}^{-1}$ değerinde iken, en düşük konsantrasyon Anchuza azurea var. azurea bitkisinin $0,3234 \mathrm{mg} \mathrm{kg}^{-1}$ gövde örneklerinde belirlenmiştir. Araştırma alanından topladığımız bu bitki örnekleri yaptığımız analiz verilerine göre $\mathrm{Cu}$ bakımından biyoakümülatör özellik gösteriyor diyemeyiz.

Mangan (Mn), bitkiler için önemli bir mikro besleyicidir ve çeşitli enzimlerin aktivitesinde önemli bir rol oynamaktadır. Köklerde Mn'nin yüksek birikimi, sedimentlerde dikkate değer bir kullanılabilirlik anlamına gelmektedir [25]. Allen (1989)'e göre Mn aralığı 50-500 mg kg-1 bitkiler için toksik olarak kabul edilir, sedimentlerde ise $5-500 \mathrm{mg} \mathrm{kg}^{-1}$ 'dır [26]. Bu nedenle köklerde ve yapraklarda bulunan konsantrasyonlar bitki yaşamı için tehlikelidir. Mn varlığı, çelik malzemelerin imalatıyla ve gübrelerin kullanımı ile bağlantılı olmalıdır [24]. Mn miktarının ölçülebilen en yüksek 
konsantrasyonu 4,465 mg kg${ }^{-1}$ değeri ile Achiella vermicularis bitkisinin kök kısmına aittir. Ölçülebilen en düşük Mn konsantrasyonu yine aynı bitkinin gövde kısmında $1,067 \mathrm{mg} \mathrm{kg}^{-1}$ olarak belirlenmiştir.

Nikel (Ni), Bazı çalışmalar sonucunda [27-28] çeşitli bitki organlarındaki biyoakümülasyon değerleri göz önüne alındığında Ni'nin bitkiler üzerinde toksik etkileri olduğu düşünülmektedir. Bragato vd. (2006) [20] yaptı̆̆ı çalışmada büyüme döneminin sonunda yaprakların $60 \mathrm{mg} \mathrm{kg}{ }^{-1} \mathrm{e}$ kadar birikebileceğini gösterdi. Allen'e (1989) göre, bitkilerdeki Ni konsantrasyonları $5 \mathrm{mg} \mathrm{kg}^{-1}$ in üzerinde zehirlidir. Sonuç olarak, yalnızca köklerde konsantrasyon tehlikeli olarak düşünülebilir.

Allen'e (1989) göre, bitkilerde bulunması gereken Ni konsantrasyonu $0,5-5 \mathrm{mg} \mathrm{kg}^{-1}$, sediment örneklerinde ise $5-500 \mathrm{mg} \mathrm{kg}^{-1}$ 'dır [26]. FAO/WHO'nun bitkilerde kabul ettiği Ni sınır değeri $5 \mathrm{mg}$ $\mathrm{kg}^{-1}$ dır. Analizi yapılan bitkiler arasında Anchuza azurea var. azurea bitkisinin kökündeki Ni konsantrasyonu en yüksek seviyede $\left(0,3077 \mathrm{mg} \mathrm{kg}^{-1}\right)$ bulunmuştur. Buna karşıll1k bu bitkiler arasında Achiella vermicularis bitkisinin gövde kısmındaki Ni konsantrasyonu ise en düşük konsantrasyonda $\left(0,0317 \mathrm{mg} \mathrm{kg}^{-1}\right)$ tespit edilmiştir. Analiz sonucu bu bitkilerdeki Ni konsantrasyonları göz önüne alındığında bitkiler için kabul edilen sınır değerleri içerisinde olduğu tespit edilmiştir.

Kurşun (Pb), bitki organizmaları için esansiyel değildir ve toksik olabilir. Pb, toprakta oldukça hareketsizdir ve köklerde birikme eğilimi gösterir ve toprak üstü organlara doğru seyrek translokasyona neden olur [21]. Bu çalışmada bulunan $\mathrm{Pb}$ konsantrasyonları, çeşitli yazarlar tarafından, özellikle yaprak ve saplar açısından bildirilen değerlerden daha yüksekti [28-29]. Bunun nedeni, Pb kirliliğinin birincil kaynağı olan araçların egzoz dumanı ve bunun sonucu olarak, yer üstü organların doğrudan etkilenmesinden kaynaklanıyor olabilir. Ayrıca bitki kök örneklerinin diğer bitki kısımlarına göre, daha fazla kurşun içermesi kurşunun bitkide hareketinin yavaş olduğunu ve kökler tarafından daha fazla tutulduğunu göstermektedir. Kurşun konsantrasyonun sediment $>$ kök $>$ gövde $>$ yaprak şeklinde sıralanması ve her iki bitkinin de kurşun kirliliğinin biyomonitörü olarak kullanılabilmesi ile ilgili bulgularımız, benzer çalışmalarda da ortaya konmuştur [26,30-32]. Allen (1989)'e göre, sucul ortam sedimentlerinde kurşun konsantrasyonunun normal değerleri $2-20 \mathrm{mg} \mathrm{kg}^{-1}$, bitkilerde ise $0,05-3 \mathrm{mg}$ $\mathrm{kg}^{-1}$ dir [26].

FAO/WHO'nun bitkilerde kabul ettiği $\mathrm{Pb}$ sınır değeri $2 \mathrm{mg} \mathrm{kg}{ }^{-1}$ 'dır. Yaptığımız analizler sonucunda $\mathrm{Pb}$ konsantrasyonu en yüksek seviyede $0,031 \mathrm{mg} \mathrm{kg}^{-1}$ değeri ile Achiella vermicularis bitkisinin yaprak kısmında, en düşük konsantrasyon ise Anchuza azurea var. azurea bitkisinin 0,002368 $\mathrm{mg} \mathrm{kg}^{-1}$ olarak gövde kısmında tespit edilmiştir. Bununla birlikte, tüm bitki organlarında saptanan $\mathrm{Pb}$ konsantrasyonları Roos'a (1994) [33] göre belirtilen fitotoksik aralığın (30-300 $\mathrm{mg} \mathrm{kg}^{-1}$ ) altındadır. Ayrıca yukarıdaki verilerle analiz sonuçlarımız karşılaştırıldığında tüm bitki örneklerindeki Pb değeri bitkiler için kabul edilen kurşun sınır değerleri içerisinde olduğu görülmektedir.

Çinko (Zn), bitki besleme ve enzimatik faaliyetlerde önemli rol oynamaktadır. Rizomlar, gövde ve yapraklarda tespit edilen konsantrasyon değerleri çeşitli yazarlar ile uyumluydu [27-29]. Köklerdeki değerler, Quan vd. (2007) [34] tarafindan bulunan Zn değerlerine benzerdir. Dahası, kökler Zn akümülatörleri olma eğilimindedir [35]. Çeşitli çalışmalar, Zn'nin büyüme mevsimi boyunca değişken olduğunu göstermektedir. Gerçekten de vejetatif dönemde Zn konsantrasyonu düşer [35]. Ancak, bazı bilim adamları ise böyle bir düşüşün anlamlı olmadığını belirtmektedir [20]. Zn konsantrasyonları, Chaney (1989) [18] tarafından önerilen fitotoksik aralıkta (500-1.500 mg kg-1) bulunmamaktadır. Bu alandaki ana kaynak $\mathrm{Zn}$ arıtma çamuru ve gübrelerdir. $\mathrm{P}$. australis ayrıca $\mathrm{Cd}, \mathrm{Pb}$ ve $\mathrm{Zn}$ 'ye karşı doğuştan gelen bir hoşgörüye sahip olabilir, çünkü yetersiz deliller, metal kontamine alanlarda yaşayan yaygın kamış populasyonlarının bir $\mathrm{Cd}, \mathrm{Pb}$ veya $\mathrm{Zn}$ tolerant eko-tipe dönüştüğü fikrini desteklemektedir [14].

Allen (1989)'e göre, bitkilerde Zn için normal konsantrasyon 10-100 mg kg-1, sedimentte ise 1$40 \mathrm{mg} \mathrm{kg}^{-1}$ aralığındadır [26,30]. FAO/WHO'nun bitkilerde kabul ettiği Zn sınır değeri $50 \mathrm{mg} \mathrm{kg}^{-1}$ ' dır. Çalıştığımız bitki örnekleri arasında Zn konsantrasyonu bakımından en yüksek değere sahip bitki 5,461 $\mathrm{mg} \mathrm{kg}^{-1}$ konsantrasyon değeriyle Anchuza azurea var. azurea bitkisinin yaprak kısmıdır. En düşük Zn konsantrasyonu ise $0,6165 \mathrm{mg} \mathrm{kg}^{-1}$ değeri ise yine aynı bitkinin gövde kısmına aittir. Çalışmamızda kullanılan bitkilerin analizleri sonucunda elde ettiğimiz veriler, $\mathrm{Zn}$ için literatürlerde belirtilen normal konsantrasyon olarak kabul edilen değerlerin altında tespit edilmiştir.

Demir (Fe), Allen (1989)'e göre, sedimentlerde bulunmas1 gereken Fe konsantrasyonu 50$1.000 \mathrm{mg} \mathrm{kg}^{-1}$, kirlenmemiş ortamlardaki bitkiler için ise $40-500 \mathrm{mg} \mathrm{kg}^{-1}$ 'dır [26]. FAO/WHO'nun bitkilerde kabul ettiği Fe sınır değeri $30 \mathrm{mg} \mathrm{kg}^{-1}$ 'dır. Bitkiler demiri topraktan $\mathrm{Fe}^{+3}, \mathrm{Fe}^{+2}$ iyonları ve $\mathrm{Fe}$ halinde almaktadırlar. Bitkilerin demir kapsamları türlerine, yaşlarına, organlarına, yetiştikleri toprakların yarayışlı demir miktarına göre, kuru ağırlıklarının birkaç ppm ile 500-600 ppm arasında 
değişmektedir [36]. Fe miktarının ölçülebilen en yüksek konsantrasyonu 50,29 $\mathrm{mg} \mathrm{kg}^{-1}$ değeri ile Anchuza azurea var. azurea bitkisinin kök kısmına aittir. Ölçülebilen en düşük Fe konsantrasyonu Achiella vermicularis bitkisinin gövde örneklerinde $4,896 \mathrm{mg} \mathrm{kg}^{-1}$ olarak belirlenmiştir. Bu değerler dikkate alındığı zaman Anchuza azurea var. azurea bitkisinin, FAO/WHO'nun bitkilerde kabul ettiği Fe sınır değerinin oldukça üzerinde olduğu görülmüştür.

Kalsiyum (Ca), diğer bitki besin elementlerine göre yer kabuğunda daha yaygın ve daha fazla bulunmaktadır. Yer kabuğunun kalsiyum kapsamı \% 3,64'tür. Bitkilerde kalsiyum eksikliği verimi azalttığı gibi kalitesinde de düşüşe sebep olmaktadır. Toprakta kalsiyum miktarında azalma olmas1 bitkinin gelişimini olumsuz etkilemektedir. Topraktaki kalsiyum eksikliğinde toprağa yan ürün olarak kalsiyum gübreleri kullanılmakta ve bitkinin temel besin maddesinden biri olan kalsiyumu bünyesine alması sağlanmaktadır. Kalsiyumlu gübreleme toprak şartları ve bitki çeşidine bağlı olarak toprak ve yaprak yoluyla yapılabilmektedir. Kalsiyum bitki bünyesinde hareketsiz bir elementtir ve yaprak yoluyla verilen kalsiyumdan genellikle daha çabuk cevap alınabilmektedir [37]. İncelenen alandaki bitki türleri arasında Ca konsantrasyonunun en yüksek olduğu bitki türü Anchuza azurea var. azurea'dır. $\mathrm{Bu}$ bitkinin yaprak kısmındaki Ca miktarı 594,1 mg kg-1 olarak belirlenmiştir. En düşük $\mathrm{Ca}$ konsantrasyonuna sahip bitki ise Hypericum scabrum' dur. Bu bitkinin organları arasında en düşük Ca konsantrasyonu $0,642 \mathrm{mg} \mathrm{kg}^{-1}$ ile gövdeye aittir.

Magnezyum (Mg), kök ve gövdenin büyüme uçlarında birikir. Gelişme döneminin sonuna doğru magnezyum genç vejetatif organlardan tohuma taşınır ve tohumda birikir. Eğer tohumun oluşumu herhangi bir nedenle gerilerse bitkinin daha uzun süre yeşil kaldığı görülür. Mg bitki bünyesinde hareketli olup hareket yönü yaşlı organlardan genç organlara doğrudur. Dolayısıyla magnezyumun eksiklik belirtileri ilk bitkinin alt tarafındaki yaşlı yapraklarında görülür. Mg noksanlığında klorofil oluşumunun azalması nedeniyle yapraklarda sarılık kloroz belirtisi ortaya çıkar. Mg noksanlığında yaprağın her tarafının sarı renk almasına karşın yaprak damarları yeşil kalır. Bitkilerde magnezyumun çoğunlukla hücre öz suyunda inorganik maddeler halinde, klorofilin yap1 maddesi olarak ve protoplazmada bileşikler halinde bulunduğuna inanılmıştır. Mg bitkilerde kalsiyuma oranla çoğunlukla daha az bulunur. Bitkilerde ortalama \% 0,30 magnezyum bulunmasına karşın \% 0,77 kalsiyumun bulunduğu saptanmıştır. $\mathrm{Mg}$ bitkilerin diğer organlarına oranla yaprak ve tohumlarında daha fazla miktarda bulunur [36]. Nitekim bizim çalı̧̧mamızda da Mg konsantrasyonu Hypericum scabrum bitkisinin yaprağında $\left(287,3 \mathrm{mg} \mathrm{kg}^{-1}\right)$ diğer organlara oranla daha fazla olduğu belirlenmiştir. En düşük $\mathrm{Mg}$ konsantrasyonu ise $54,86 \mathrm{mg} \mathrm{kg}^{-1}$ değeri ile Anchuza azurea var. azurea' nın gövdesinde tespit edilmiştir.

Yaptığımız analizler sonucunda çalıştığımız bitkilerin dokularında biriktirdiği $\mathrm{Mg}, \mathrm{Cr}, \mathrm{Mn}, \mathrm{Ni}$, $\mathrm{Cu}, \mathrm{Zn}, \mathrm{Cd}, \mathrm{Pb}, \mathrm{Ca}$ ağır metal yoğunluklarının toksiteye neden olacak seviyelere ulaşmadığ görülmüştür. Sadece Fe bakımından Anchuza azurea var. azurea bitkisinin, FAO/WHO'nun bitkilerde kabul ettiği Fe sınır değerinin oldukça üzerinde olduğu görülmüştür.

Tablo 1. Çalışma Alanından Alınan Toprak Numune Değerleri

\begin{tabular}{|c|c|c|c|c|c|c|c|c|c|c|}
\hline TÜRLER & Mg & $\mathrm{Cr}$ & Mn & $\mathbf{F e}$ & $\mathbf{N i}$ & $\mathbf{C u}$ & $\mathbf{Z n}$ & Cd & $\mathbf{P b}$ & $\mathbf{C a}$ \\
\hline Toprak 1 & 72,15 & 0,3998 & 39,83 & 779,9 & 0,4041 & 0,4117 & 6,857 & 0,0608 & 2,022 & 5,532 \\
\hline Toprak 2 & 408,2 & 3,237 & 83,59 & 1683 & 3,307 & 1,23 & 9,523 & 0,0870 & 2,161 & 23,49 \\
\hline Toprak 3 & 412,4 & 5,874 & 168,3 & 3132 & 7,697 & 2,34 & 13,15 & 0,1167 & 3,113 & 67,10 \\
\hline
\end{tabular}

Toprak örneklerinde $\mathrm{Mg}, \mathrm{Cr}, \mathrm{Mn}, \mathrm{Fe}, \mathrm{Ni}, \mathrm{Cu}, \mathrm{Zn}, \mathrm{Cd}, \mathrm{Pb}$ ve $\mathrm{Ca}$ elementlerinin ortalama konsantrasyonları sirasiyla 297,58; 3,17; 97,24; 1864,96;3,80;1,32;9,84; 0,$08 ; 2,46 ; 32,04 \mathrm{mg} \mathrm{kg}^{-1}$ olarak tayin edilmiştir (Tablo 1). Bitki türlerinin yayılış gösterdiği 3 farklı istasyondan alınan toprak örneklerindeki ağır metal konsantrasyonları mangan $(\mathrm{Mn})$ ve demir $(\mathrm{Fe})$ hariç, Toprak Kirliliğinin Kontrolü Yönetmeliğinde verilen topraktaki ağır metal sınır değerlerinin (Tablo 2) altında tespit edildi. Toprakta tolere edilebilir Fe değerleri sırasıyla şöyledir; $0,2 \mathrm{mg} / \mathrm{kg}$ 'ın altında ise az, 0,2- 4,5 mg/kg arasinda orta ve $4,5 \mathrm{mg} / \mathrm{kg}$ ' dan fazla ise genellikle yüksek ve toksik olarak kabul edilmektedir [38]. Elde ettiğimiz analiz sonuçlarına bakıldığında toprakta tespit edilen Fe miktarı oldukça yüksek olduğundan toksik etki gösterebilir. 
Tablo 2. Topraktaki ağır metal sınır değerleri (mg/kg) [39]

\begin{tabular}{|c|c|c|}
\hline Ağır Metal & pH 5-6 (mg/kg kuru toprak) & pH>6 (mg/kg kuru toprak) \\
\hline $\mathrm{Pb}$ & 50 & 300 \\
\hline $\mathrm{Cd}$ & 1 & 3 \\
\hline $\mathrm{Ni}$ & 30 & 75 \\
\hline $\mathrm{Cr}$ & 100 & 100 \\
\hline Co & 80 & 80 \\
\hline $\mathrm{Cu}$ & 50 & 140 \\
\hline $\mathrm{Fe}$ & 4,5 & 4,5 \\
\hline $\mathrm{Zn}$ & 150 & 300 \\
\hline $\mathrm{Mn}$ & 70 & 70 \\
\hline
\end{tabular}

Tablo 3. Çalışma alanındaki Anchusa azurea Miller var. azurea Gard. Dict. bitkisinin organlarındaki ağır metal

\begin{tabular}{llllllllllll}
\hline Tür & Organlar & $\mathbf{M g}$ & $\mathbf{C r}$ & $\mathbf{M n}$ & $\mathbf{F e}$ & $\mathbf{N i}$ & $\mathbf{C u}$ & $\mathbf{Z n}$ & $\mathbf{C d}$ & $\mathbf{P b}$ & $\mathbf{C a}$ \\
\hline & Kök & 63,6 & $\begin{array}{l}\text { Tespit } \\
\text { edilemedi }\end{array}$ & 1,372 & 50,29 & 0,2166 & 0,5611 & 2,286 & 0,00544 & 0,02969 & 434,400 \\
$\begin{array}{l}\text { Anchuza } \\
\text { azurea } \\
\text { var. azurea }\end{array}$ & Gövde & 54,86 & $\begin{array}{l}\text { Tespit } \\
\text { edilemedi }\end{array}$ & 1,096 & 6,059 & 0,0914 & 0,3234 & 0,6165 & 0,001883 & 0,002368 & 215,700 \\
& Y̧çek & 158,7 & $\begin{array}{l}\text { Tespit } \\
\text { edilemedi }\end{array}$ & 1,246 & 14,79 & 0,0996 & 0,7887 & 1,882 & 0,003138 & 0,02227 & 372,000 \\
& Yaprak & 137,4 & $\begin{array}{l}\text { Tespit } \\
\text { edilemedi }\end{array}$ & 2,468 & 35,73 & 0,3077 & 0,7369 & 5,461 & 0,001884 & 0,023 & 594,100 \\
\hline
\end{tabular}

Anchusa azurea Miller var. azurea Gard. Dict. bitkisinin kökünde ağır metal konsantrasyonundaki azalma eğilimi $\mathrm{Ca}>\mathrm{Mg}>\mathrm{Fe}>\mathrm{Zn}>\mathrm{Mn}>\mathrm{Cu}>\mathrm{Ni}>\mathrm{Pb}>\mathrm{Cd}$, gövdede $\mathrm{Ca}>\mathrm{Mg}>\mathrm{Fe}>\mathrm{Mn}>\mathrm{Zn}>\mathrm{Cu}>\mathrm{Ni}>\mathrm{Pb}>\mathrm{Cd}$, çiçekte $\mathrm{Ca}>\mathrm{Mg}>\mathrm{Fe}>\mathrm{Zn}>\mathrm{Mn}>\mathrm{Cu}>\mathrm{Ni}>\mathrm{Pb}>\mathrm{Cd}$ ve yaprakta $\mathrm{Ca}>\mathrm{Mg}>\mathrm{Fe}>\mathrm{Zn}>\mathrm{Mn}>\mathrm{Cu}>\mathrm{Ni}>\mathrm{Pb}>\mathrm{Cd}$ tespit edildi. $\mathrm{Cr}$ ise bu bitkinin dört farklı organında yaptığımız analizlerde tespit edilemedi (Tablo 3.).

Tablo 4. Çalışma Alanındaki Achillea vermicularis Trin. bitkisinin organlarındaki ağır metal değerleri

\begin{tabular}{llllllllllll}
\hline Türler & Organlar & $\mathbf{M g}$ & $\mathbf{C r}$ & $\mathbf{M n}$ & $\mathbf{F e}$ & $\mathbf{N i}$ & $\mathbf{C u}$ & $\mathbf{Z n}$ & $\mathbf{C d}$ & $\mathbf{P b}$ & $\mathbf{C a}$ \\
\hline \multirow{4}{*}{$\begin{array}{l}\text { Achiella } \\
\text { vermicularis }\end{array}$} & Kövde & 71,78 & $\begin{array}{l}\text { Tespit } \\
\text { Kök }\end{array}$ & 1,067 & 4,896 & 0,0317 & 0,3717 & 1,151 & 0,02511 & $\begin{array}{l}\text { Tespit } \\
\text { edilemedi }\end{array}$ & 24,800 \\
& Çiçek & 215 & $\begin{array}{l}\text { Tespit } \\
\text { edilemedi }\end{array}$ & 2,893 & 27,96 & 0,2293 & 0,7311 & 4,584 & 0,04666 & 0,02421 & 13,24 \\
& Yespit & 2,744 & 8,842 & 0,1801 & 1,197 & 5,205 & 0,01524 & 0,01689 & 225,300 \\
& Yaprak & 145,1 & $\begin{array}{l}\text { edilemedi } \\
\text { Tespit } \\
\text { edilemedi }\end{array}$ & 4,465 & 35,27 & 0,2826 & 0,9998 & 4,565 & 0,0317 & 0,031 & 372,000 \\
\hline
\end{tabular}

Achillea vermicularis Trin. bitkisinin gövdesinde ağır metal konsantrasyon miktarındaki değişim $\mathrm{Mg}>\mathrm{Ca}>\mathrm{Fe}>\mathrm{Zn}>\mathrm{Mn}>\mathrm{Cu}>\mathrm{Ni}>\mathrm{Cd}$, kökte $\mathrm{Mg}>\mathrm{Fe}>\mathrm{Ca}>\mathrm{Zn}>\mathrm{Mn}>\mathrm{Cu}>\mathrm{Ni}>\mathrm{Cd}>\mathrm{Pb}$, çiçekte $\mathrm{Ca}>\mathrm{Mg}>\mathrm{Fe}>\mathrm{Zn}>\mathrm{Mn}>\mathrm{Cu}>\mathrm{Ni}>\mathrm{Pb}>\mathrm{Cd}$ ve yaprakta $\mathrm{Ca}>\mathrm{Mg}>\mathrm{Fe}>\mathrm{Zn}>\mathrm{Mn}>\mathrm{Cu}>\mathrm{Ni}>\mathrm{Cd}>\mathrm{Pb}$ tespit edildi. $\mathrm{Cr}$ ise bu bitkinin dört farklı organında yaptığımız analizlerde tespit edilemedi (Tablo 4).

Tablo 5. Çalışma Alanındaki Hypericum scabrum L. bitkisinin organlarındaki ağır metal değerleri

\begin{tabular}{|c|c|c|c|c|c|c|c|c|c|c|c|}
\hline Türler & Organlar & Mg & $\mathrm{Cr}$ & Mn & $\mathbf{F e}$ & $\mathbf{N i}$ & $\mathbf{C u}$ & $\mathbf{Z n}$ & Cd & $\mathbf{P b}$ & $\mathbf{C a}$ \\
\hline \multirow{4}{*}{$\begin{array}{l}\text { Hypericum } \\
\text { scabrum }\end{array}$} & Çiçek & 181,5 & $\begin{array}{l}\text { Tespit } \\
\text { edilemedi }\end{array}$ & 1,867 & 23,03 & 0,06166 & 1,725 & 4,624 & 0,01465 & 0,005137 & 127,700 \\
\hline & Yaprak & 287,3 & $\begin{array}{l}\text { Tespit } \\
\text { edilemedi }\end{array}$ & 3,043 & 19,96 & 0,2314 & 0,6747 & 4,653 & 0,07846 & 0,005642 & 230,700 \\
\hline & Kök & 82,19 & $\begin{array}{l}\text { Tespit } \\
\text { edilemedi }\end{array}$ & 2,139 & 37,38 & 0,1287 & 1,052 & 1,732 & 0,07721 & 0,02285 & 38,550 \\
\hline & Gövde & 95,57 & $\begin{array}{l}\text { Tespit } \\
\text { edilemedi }\end{array}$ & 1,242 & 5,063 & 0,06753 & 0,5984 & 1,126 & 0,09384 & $\begin{array}{l}\text { Tespit } \\
\text { edilemedi }\end{array}$ & 0,642 \\
\hline
\end{tabular}


Hypericum scabrum L. bitkisinin çiçeğinde ağır metal konsantrasyonundaki azalma eğilimi $\mathrm{Mg}>\mathrm{Ca}>\mathrm{Fe}>\mathrm{Zn}>\mathrm{Mn}>\mathrm{Cu}>\mathrm{Ni}>\mathrm{Cd}>\mathrm{Pb}$, yaprağında $\mathrm{Mg}>\mathrm{Ca}>\mathrm{Fe}>\mathrm{Zn}>\mathrm{Mn}>\mathrm{Cu}>\mathrm{Ni}>\mathrm{Cd}>\mathrm{Pb}$, kökünde $\mathrm{Mg}>\mathrm{Ca}>\mathrm{Fe}>\mathrm{Mn}>\mathrm{Zn}>\mathrm{Cu}>\mathrm{Ni}>\mathrm{Cd}>\mathrm{Pb}$ ve gövdede $\mathrm{Mg}>\mathrm{Fe}>\mathrm{Mn}>\mathrm{Zn}>\mathrm{Ca}>\mathrm{Cu}>\mathrm{Cd}>\mathrm{Ni}$ tespit edildi. $\mathrm{Cr}$ ise bu bitkinin dört farklı organında yaptığımız analizlerde tespit edilemedi (Tablo 5).

\section{Sonuç ve Öneriler}

\section{5.}

Araştırmamız sonucunda çalışma alanından toplanan bu 6 bitki türünün dokularında biriktirdiği $\mathrm{Mg}, \mathrm{Cr}$, $\mathrm{Mn}, \mathrm{Fe}, \mathrm{Ni}, \mathrm{Cu}, \mathrm{Zn}, \mathrm{Cd}, \mathrm{Pb}$ ve $\mathrm{Ca}$ elementlerinin yoğunluklarının toksisiteye neden olacak seviyelere ulaşmadığ 1 görülmüsşür. Ancak Anchusa azurea Miller var. azurea Gard. Dict. türü FAO/WHO'nun bitkilerde kabul ettiği Fe sınır değerinin oldukça üzerinde olduğu görülmüştür. Dolayısıyla Anchusa azurea var. azurea bitkisi Fe bakımından kirlenmiș toprakların temizlenmesinde denenebilir. Tür sayısı ve çeşitliliği bakımından oldukça zengin bir floraya sahip olan ülkemizde yaptığımız araştırmalara benzer çalışmaların sayısını artırmayı teşvik ettiğimizde, hiperakümülatör özelliğine sahip tür sayısı ve çeşitliliği artmış olacaktır. Böylece kirlenmiş toprakların temizlenmesinde kullanılan birçok pahalı yöntemden kurtularak ülke ekonomimize önemli bir katkı sağlarken, gelecek nesillere ise temiz ve yaşanılabilir bir çevre miras olarak bırakılacaktır.

\section{Teşekkür}

Bu çalışma 2017/12 nolu proje kapsamında Bitlis Eren Üniversitesi Bilimsel Araştırmalar Projeleri Koordinatörlügüne (BEBAP) tarafından desteklenmiş olup ikinci yazarın yüksek lisans tezinden özetlenmiştir.

\section{Kaynaklar}

[1] Urano K., Kurihara Y., Seki M., Shinozaki K. 2010. 'Omics’ Analyses of Regulatory Networks in Plant Abiotic Stress Responses. Current Opinion in Plant Biology. 13: 132-138.

[2] Long X.X., Yang X.E., Ni W.Z. 2002. Current Status and Perspective on Phytoremediation of Heavy Metal Polluted Soils. Journal of Applied Ecology. 13: 757-762.

[3] Blaylock M.J., Huang J.W. 2000. Phytoextraction of Metals. In: Raskin, I. and Ensley, B.D. (eds.), Phytoremediation of Toxic Metals: Using Plants to Clean-up the Environment. Wiley, New York.

[4] Yalçuk A., Evirgen O.A., Uğurlu A. 2004. Tehlikeli Atık Sahalarında Yetişen Hiperakümülatör Bitkiler. 6. Ulusal Kimya Mühendisliği Kongresi, 7-10 Eylül 2004, İzmir.

[5] Davis P.H. 1988. Flora of Turkey and the East Aegean Islands. Edinburgh, Edinburgh University Press, pp. 266-400.

[6] Tanker N. 1971. Studies on Hypericum scabrum L. J Fac Pharm Ankara Univ., 1: 10-15.

[7] Azırak S., Erdoğrul Ö.T. 2003. Antibacterial activities of Hypericum scabrum. ISOPS-7: International Symposium on Pharmaceutical Sciences-7, Ankara University, Faculty of Pharmacy Publications, No: 87. Proceedings and Abstracts, June 23-26, Ankara, Turkey, pp. 17-21.

[8] Erdoğrul Ö.T., Azırak S., Tosyalı C. 2004. Antimicrobial activities of Hypericum scabrum L. extracts. KSU J Sci Eng., 7: 38-42.

[9] Davis P.H. 1975. Flora of Turkey and the East Aegean Islands. Vol. 5, p. 465-585. Edinburgh University Press.

[10] Davis P.H. 1978. Flora of Turkey and the East Aegean Islands. Vol. 6, Edinburgh University Press.

[11] Divan Jr A.M., De Oliveira P.L., Perry C.T., Atz V.L., Azzarini-Rostirola L.N., Raya-Rodriguez M.T. 2009. Using wild plant species as indicators for the accumulation of emissions from a thermal power plant, Candiota, South Brazil. Ecol. Indic. 9: 1156-1162.

[12] Hernândez L.E., Lozano E., Gârate A., Carpena R. 1998. Influence of cadmium on the uptake, tissue accumulation and subcellular distribution of manganese in pea seedlings. Plant Sci. 132: 139-151.

[13] Foyer C.H., Lelandais M., Kunert K.J. 1994. Photooxidative stress in plants. Physiol. Plantarum, 92: 696-717. 
[14] Ye Z.H., Baker A.J.M., Wong M.H., Willis A.J. 1997. Zinc, lead and cadmium tolerance, uptake and accumulation by the common reed, Phragmites australis (Cav.) Trin. ex Steudel. Ann. Bot. 80: $363-370$.

[15] Ederli L., Reale L., Ferranti F., Pasqualini S. 2004. Responses induced by high concentration of cadmium in Phragmites australis roots. Physiol Plant. 121: 66-74.

[16] Pietrini F., Iannelli M.A., Pasqualini S., Massacci A. 2003. Interaction of cadmium with glutathione and photosynthesis in developing leaves and chloroplasts of Phragmites australis (Cav.) Trin. Ex Steudel. Plant Physiol., 133: 829-837.

[17] Madejôn P., Marañôn T., Murillo J.M., Robinson B. 2004. White poplar (Populus alba) as a biomonitor of trace elements in contaminated riparian forests. Environ. Pollut. 132: 145-155.

[18] Chaney R.L. 1989. Toxic element accumulation in soils and crops: protecting soil fertility and agricultural food chains. In: Bar-Yosef B, Barrow N.J, Goldshmid J. (Eds.), Inorganic Contaminants in the Vadose Zone. Springer-Verlag, Berlin, 140-158.

[19] Allen S.E. 1989. Chemical Analysis of Ecological Material, 2nd edition. Blackwell Scientific Publications, Oxford, 368 pp.

[20] Bragato C., Brix H., Malagoli M. 2006. Accumulation of nutrients and heavy metals in Phragmites australis (Cav.) Trin. ex Steudel and Bolboschoenus maritimus (L.) Palla in a constructed wetland of the Venice lagoon watershed. Environ. Pollut., 144: 967-975.

[21] Siedlecka A., Tukendorf A., Skórzynska-Polit E., Maksymiec W., Wónjcik M., Baszynski T., Krupa Z. 2001. Angiosperms (Asteraceae, Convolvulaceae, Fabaceae and Poaceae; other than Brassicaceae). In: Prasad M.N.V. (Ed.), Metals in the Environment. Analysis by Biodiversity. Marcel Dekker Inc, New York, 171-217.

[22] Yruela I. 2005. Copper in Plants. Brazilian J. Plant Phys. 17: 145-156.

[23] Fürtig K., Pavelic D., Brunold C., Brändle R. 1999. Copper-and-iron induced injuries in roots and rhizomes of reed (Phragmites australis). Limnologica, 29: 60-63.

[24] Bonanno G., Giudice R. Lo. 2010. Heavy metal bioaccumulation by the organs of Phragmites australis (common reed) and their potential use as contamination indicators. Department of Agronomic and Agrochemical Sciences and Animal Productions, University of Catania, via Valdisavoia 5, 95123 Catania, Sicily, Italy Ecological Indicators, 10: 639-645.

[25] Baldantoni D., Alfani A., Di Tommasi P., Bartoli G., Virzo De Santo A. 2004. Assessment ofmacro and microelement accumulation capability of two aquatic plants. Environ. Pollut. 130: 149-156.

[26] Demirezen D. 2002. Sultan Sazlığı ve Çevresindeki Sucul Ekosistemlerde Ağır Metal Kirliliğinin İncelenmesi. Gazi Üniversitesi, Fen Bilimleri Enstitüsü, Doktora Tezi.

[27] Samecka-Cymerman A., Kempers A.J. 2001. Concentrations of heavy metals and plant nutrients in water, sediments and aquatic macrophytes of anthropogenic lakes (former open cut brown coal mines) differing in stage of acidification. Sci. Total Environ. 281: 87-98.

[28] Lesage E., Rousseau D.P.L., Meers E., Tack F.M.G., De Pauw N. 2007. Accumulation of metals in a horizontal subsurface flow constructed wetland treating domestic wastewater in Flanders, Belgium. Sci. Total Environ. 380: 102-115.

[29] Vymazal J., Svehla J., Kröpfelová L., Chrastný V. 2007. Trace metals in Phragmites australis and Phalaris arundinacea growing in constructed and natural wetlands. Sci. Total Environ., 380: 154-162.

[30] Duman F. 2001. Sarımsaklı - Karasu'da yetişen Phragmites australis (Cav.) Trin ex.steud ve Typha angustifolia L. Bitkileri ve Bunları Çevreleyen Sedimentlerde Ağır Metal Tayini, Y. Lisans Tezi, E. Ü. Fen Bil. Enst., Kayseri.

[31] Windham L., Weis J.S., Weis P. 2003. Uptake and distribution of metals in two dominant salt macrophytes, Spartania alternifolia (cordgrass) and Phragmites australis (common reed). Estuarine, Coastal and Shelf Science. 56: 63-72.

[32] Demirezen D., Aksoy A. 2004. Accumulation of heavy metals in Typha angustifolia (L.) and Potamogeton pectinatus (L.) living in Sultan Marsh (Kayseri, Turkey). Chemosphere, 56: 685696.

[33] Roos M.S. 1994. Sources and forms of potentially toxic metals in soil-plant systems. In: Ross M.S. (Ed.), Toxic Metals in Soil-Plant System. John Wiley, Chichester, pp. 3-25. 
[34] Quan W.M., Han J.D., Shen A.L., Ping X.Y., Qian P.L., Li C.J., Shi L.Y., Chen Y.Q. 2007. Uptake and distribution of N, P and heavy metals in three dominant salt marsh macrophytes from Yangtze River estuary, China. Mar. Environ. Res. 64: 21-37.

[35] Weis J.S., Glover T., Weis P. 2004. Interactions of metals affect their distribution in tissues of Phragmites australis. Environ. Pollut. 131: 409-415.

[36] Güven A. 2002. Tarla Bitkileri Merkez Araştırma Enstitüsü Dergisi, 11 (1-2).

[37] Locascio S.J., Bartz J.A., Weingartner D.P. 1992. Calcium and Potassium Fertilization of Potatoes Grown in North Florida I. Effects On Potato Yield and Tissue Ca And K Concentrations. American Potato Journal, 69(2): 95-104.

[38] Lindsay W.L., Norvell W.A. 1978. Development of a DTPA Soil Test for Zinc, Iron, Manganase and Copper. Soil Sci. Soc. Am. J. 42: 421- 428.

[39] Anonim 2005. Resmi Gazete. Toprak Kirliliğinin Kontrolü Yönetmeliği. 31/05/2005 tarihli, 25831 say1l. 